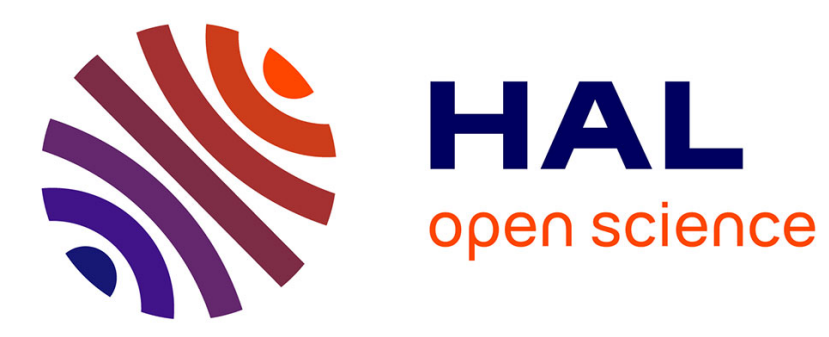

\title{
Electrochemical Alloying of Lead in Potassium-Ion Batteries
}

Vincent Gabaudan, Romain Berthelot, Lorenzo Stievano, Laure Monconduit

\section{To cite this version:}

Vincent Gabaudan, Romain Berthelot, Lorenzo Stievano, Laure Monconduit. Electrochemical Alloying of Lead in Potassium-Ion Batteries. ACS Omega, 2018, 3 (9), pp.12195 - 12200. 10.1021/acsomega.8b01369 . hal-01886583

\section{HAL Id: hal-01886583 https://hal.science/hal-01886583}

Submitted on 25 May 2021

HAL is a multi-disciplinary open access archive for the deposit and dissemination of scientific research documents, whether they are published or not. The documents may come from teaching and research institutions in France or abroad, or from public or private research centers.
L'archive ouverte pluridisciplinaire HAL, est destinée au dépôt et à la diffusion de documents scientifiques de niveau recherche, publiés ou non, émanant des établissements d'enseignement et de recherche français ou étrangers, des laboratoires publics ou privés. 


\title{
Electrochemical Alloying of Lead in Potassium-Ion Batteries
}

\author{
Vincent Gabaudan, ${ }^{\dagger,}$ Romain Berthelot, ${ }^{*}, \dagger$ Lorenzo Stievano, ${ }^{\dagger, \ddagger(0)}$ and Laure Monconduit ${ }^{\dagger, \ddagger(0)}$ \\ †ICGM, Université de Montpellier, CNRS, Montpellier 34095, France \\ ${ }^{\ddagger}$ Réseau sur le Stockage Électrochimique de l'Énergie (RS2E), CNRS, Amiens, France
}

\section{Supporting Information}

ABSTRACT: The electrochemical alloying of lead-based electrodes with potassium was investigated by galvanostatic measurements as well as by ex situ and operando X-ray diffraction. The electrochemical reduction must be activated by an initial high current pulse which prevents the passivation of the lead electrode. The alloying process leads to the formation of crystalline $\mathrm{KPb}$. During the discharge, two intermediate phases are observed, $\mathrm{K}_{10} \mathrm{~Pb}_{48}$ and $\mathrm{K}_{4} \mathrm{~Pb}_{9}$, whereas only $\mathrm{K}_{4} \mathrm{~Pb}_{9}$ seems to form during the charge. High capacity retention is observed, with, however, a limited specific capacity value because of high weight of lead.

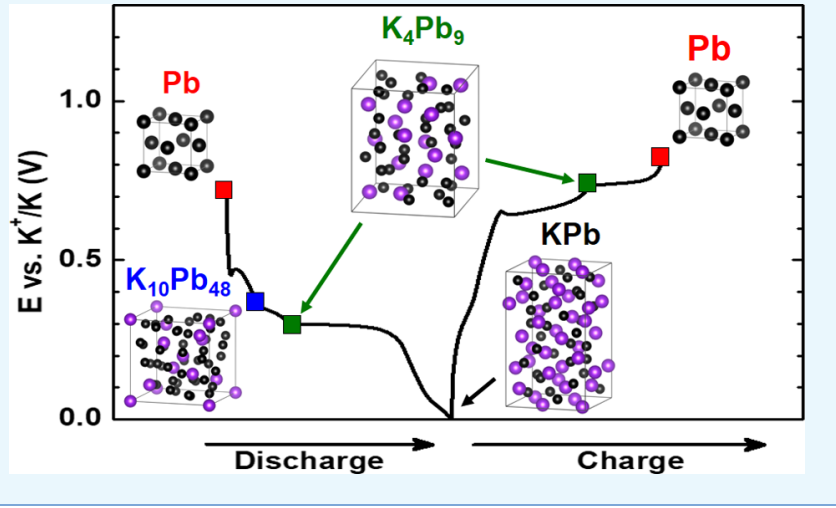

\section{INTRODUCTION}

The lithium-ion technology was originally developed to power portable electronic devices. However, it is now expanding to a growing market of electric vehicles and stationary storage devices. The considerable need for lithium-ion batteries (LIBs) will continue to rise in the future and might be confronted with sustainability issues. ${ }^{1}$ Indeed, it is still doubtful whether the global lithium reserves can meet the demand, whereas the availability of cobalt might impact the production of highenergy-density systems. ${ }^{2}$ It is therefore important to investigate alternative electrochemical storage systems that could compete with the lithium-ion technology for some specific applications in the future. In this context, potassium-ion batteries (KIBs) have recently emerged as a possible alternative. ${ }^{3,4}$

The interest in KIBs compared to commercial LIBs or the emerging sodium-ion batteries (NIBs) is connected to (i) the high abundance and homogeneous distribution of potassium, which makes it inexpensive and less sensitive to price fluctuation, (ii) the low redox potential of the $\mathrm{K}^{+} / \mathrm{K}$ redox couple in nonaqueous electrolytes, paving the way to highenergy-density systems with cell voltages significantly higher than in NIBs, and (iii) the elevated conductivities of electrolytes for KIBs owing to the small size of the solvated potassium ion. Moreover, fast diffusion kinetics are also expected because of the low desolvation energy of $\mathrm{K}^{+}$.

The search for competitive negative or positive electrode materials, as well as for efficient electrolytes, is logically inspired by past results about LIBs and NIBs. The relatively large ionic size of potassium ions is a key parameter that limits the investigation of positive electrode materials such as layered oxides or polyanionic compounds. ${ }^{6-9}$ Organic materials have been also tested but they still exhibit too low working potentials. ${ }^{10}$ So far, Prussian blue analogs are leading the race of energy density. ${ }^{11-14}$ They are also of interest regarding sustainability and low-cost preparation.

On the opposite side, graphite and other types of carbons are now extensively investigated as negative electrode materials. ${ }^{15-18}$ Unlike $\mathrm{Na}^{+}, \mathrm{K}^{+}$can intercalate into graphite to form stage-I $\mathrm{KC}_{8}$ with a corresponding specific capacity close to the theoretical value of $279 \mathrm{~mA} \mathrm{~h} / \mathrm{g} .{ }^{16}$ However, a poor capacity retention upon cycling is observed and mainly attributed to the large volumetric expansion $(+60 \%) .{ }^{18}$ At this point, it is worth mentioning that concentrated effort is mandatory in order to establish both efficient electrode and electrolyte formulations especially for a better control of the solid-electrolyte interphase.

Beyond that, alloying electrode materials are known to offer significantly higher capacities in LIBs and NIBs. In a similar way, the electrochemical behaviors of several p-block elements have been recently evaluated in KIBs. ${ }^{19}$ Figure 1 presents the theoretical gravimetric and volumetric capacities of elements from groups 14 and 15 versus potassium. Antimony and bismuth can alloy with three potassiums, leading to relatively high volumetric capacities, whereas silicon, germanium tin, and lead react with only one potassium. The activity of phosphorus seems difficult to trigger and there is still controversy regarding the end product of the electrochemical alloying. Although the formation of $\mathrm{K}_{3} \mathrm{P}$ was initially proposed in the study of $\mathrm{Sn}_{4} \mathrm{P}_{3}$, recent works suggested a single-electron mechanism and the formation of KP alloy at the end of the electrochemical discharge, corresponding to a high specific capacity of $843 \mathrm{~mA}$ $\mathrm{h} / \mathrm{g}^{20-23}$

Received: June 18, 2018

Accepted: September 17, 2018

Published: September 28, 2018 


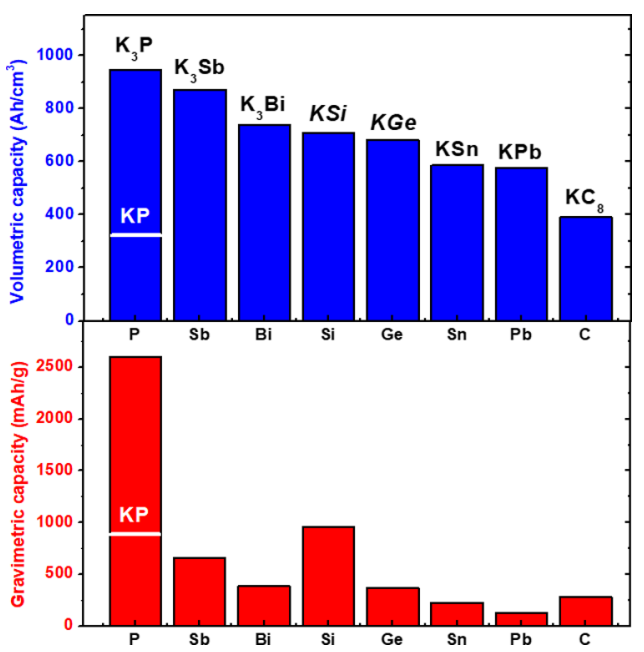

Figure 1. Theoretical gravimetric and volumetric capacities of elements from groups 14 and 15 . For $\mathrm{Si}$ and $\mathrm{Ge}$, the alloy formation was only theoretically demonstrated.

In 2015, a Sb/C nanocomposite with a high capacity of 650 $\mathrm{mA} \mathrm{h} / \mathrm{g}_{(\mathrm{Sb})}$ was reported. In this case, the buffering action of carbon apparently compensates the dramatic volumetric expansion because of the formation of $\mathrm{K}_{3} \mathrm{Sb}$. When the capacity is artificially limited to $250 \mathrm{~mA} \mathrm{~h} / \mathrm{g}_{(\mathrm{Sb})}$, the alloying is restricted to the formation of $\mathrm{KSb}$ and a better cycling is observed. ${ }^{24}$ More recently, Han et al. obtained a stable capacity of $460 \mathrm{~mA} \mathrm{~h} / \mathrm{g}_{(\mathrm{Sb}+\mathrm{C})}$ after 15 cycles with a composite electrode made of $\mathrm{Sb}$ nanoparticles confined in a three-dimensional carbon network at the current density of $200 \mathrm{~mA} / \mathrm{g}_{(\mathrm{Sb}+\mathrm{C})}{ }^{25}$ The operando X-ray diffraction (XRD) showed a two-step process with first the formation of an amorphous $\mathrm{K}_{x} \mathrm{Sb}$ phase followed by the formation of $\mathrm{K}_{3} \mathrm{Sb}$ at the end of the discharge. Also, bismuth was studied as a possible negative electrode material for KIBs. In situ XRD evidenced that the potassiation of $\mathrm{Bi}$ proceeds via the successive formation of the crystalline compounds $\mathrm{KBi}_{2}, \mathrm{~K}_{3} \mathrm{Bi}_{2}$, and finally $\mathrm{K}_{3} \mathrm{Bi}^{26}$. The use of potassium bis(fluorosulfonyl)imide (KFSI) salt instead of potassium hexafluorophosphate $\left(\mathrm{KPF}_{6}\right)$ and glyme-based solvents instead of carbonate-based solvents allows improving the performance of $\mathrm{Bi}$ electrodes. ${ }^{27,28}$ Regarding tin-based electrodes, a limited capacity below $200 \mathrm{~mA} \mathrm{~h} / \mathrm{g}$ was obtained with a ball-milled $\mathrm{Sn}-\mathrm{C}$ nanocomposite, and the electrochemical mechanism shows the final formation of KSn. ${ }^{29-31}$

Because of its weight and toxicity, lead has been put aside as negative electrode material in rechargeable LIBs and NIBs for many years. This is unfortunate as high theoretical capacities are expected for the formation of $\mathrm{Li}_{22} \mathrm{~Pb}_{5}(568 \mathrm{~mA} \mathrm{~h} / \mathrm{g})$ or $\mathrm{Na}_{15} \mathrm{~Pb}_{4}(485 \mathrm{~mA} \mathrm{~h} / \mathrm{g})$. Moreover, lead is inexpensive and its extensive use for lead-acid batteries clearly shows that the risks related to the toxicity might be lowered through appropriate safe packaging. The very high recycling rate of $99 \%$ is also an important point in terms of cost. ${ }^{32}$ The reaction mechanism of lead with sodium was studied by in situ XRD, showing a fourstep process from $\mathrm{Pb}$ to $\mathrm{Na}_{15} \mathrm{~Pb}_{4}$. A poor capacity was obtained with a conventional carbonate solvent electrolyte even using a limited potential window. ${ }^{33}$ By using a glyme-based electrolyte and a specific electrode formulation, Darwiche et al. obtained a capacity of $460 \mathrm{~mA} \mathrm{~h} / \mathrm{g}$ after 50 cycles at a C/5 rate with an excellent coulombic efficiency. ${ }^{34}$ Lead was also recently investigated as a negative electrode material for magnesiumion batteries by Obrovac and co-workers. ${ }^{35}$ Sputtered Pb films exhibited reversible capacity of $450 \mathrm{~mA} \mathrm{~h} / \mathrm{g}$, corresponding to the formation of $\mathrm{Mg}_{2} \mathrm{~Pb} . \mathrm{Pb}$ anodes were reported in potassium-based dual-ion batteries with expanded graphite cathodes. The battery presented a weaker cycling stability than with $\mathrm{Sn}$ anodes, and therefore the reaction mechanism was not studied in detail. ${ }^{36}$

In this work, lead is considered as another potential negative electrode material for KIBs. According to the thermodynamic $\mathrm{K}-\mathrm{Pb}$ phase diagram, the electrochemical alloying of $\mathrm{Pb}$ with $\mathrm{K}$ leads to the full potassiated $\mathrm{KPb}$ phase, with gravimetric and volumetric capacities of $129 \mathrm{~mA} \mathrm{~h} / \mathrm{g}$ and $580 \mathrm{~mA} \mathrm{~h} / \mathrm{cm}^{3}$, respectively. Three intermediates phases, $\mathrm{K}_{2} \mathrm{~Pb}_{3}, \mathrm{KPb}_{2}$, and $\mathrm{KPb}_{4}$, are also mentioned and could be formed during the electrochemical reaction. Although the theoretical capacity is limited, this work joins the general frame of investigating alternative negative electrode material for next efficient and sustainable KIBs.

\section{RESULTS AND DISCUSSION}

A first series of electrochemical tests of $\mathrm{Pb}$ electrodes cycled at C/5 in KFSI in ethylene carbonate (EC)/diethylene carbonate (DEC) (1:1) shows galvanostatic profiles with an irregular voltage plateau around $1.3 \mathrm{~V}$ and a very limited reversible capacity (Figure S1). This phenomenon has been already observed in other electrochemical systems with alloying-type electrode materials. Dahn et al. observed an irreversible voltage plateau at $1.0 \mathrm{~V}$ for $\mathrm{SnO}$ cycled versus $\mathrm{Li}^{+} / \mathrm{Li}$ and suggested the formation of cracks caused by volume expansion. ${ }^{3}$ This phenomenon was also described by Tamura et al. for electrodeposited $\mathrm{Sn}$ cycled versus $\mathrm{Li}^{+} / \mathrm{Li}$ and by Beattie et al. who observed an anomalous irreversible voltage plateau around $1.5 \mathrm{~V}$ for electroplated and sputtered Sn electrodes. ${ }^{38,39}$ Obrovac and co-workers recently attributed this phenomenon to catalytic surface reactions of tin or lead with the electrolytes that hinder the alloying process, and proposed to bypass it by applying an initial strong current pulse. ${ }^{3,35}$

Following the latter strategy, a second series of electrochemical tests was attempted by first applying a current of $1 \mathrm{~mA}$ until the potential reaches $0.8 \mathrm{~V}$. The resulting cycling curves are strongly modified (Figure 2). During the first discharge at $\mathrm{C} / 5$, the potential decreases quickly from 0.8 to $0.4 \mathrm{~V}$; a slope change is observed with a plateau at $0.3 \mathrm{~V}$ before a sloped end with a total capacity of $157 \mathrm{~mA} \mathrm{~h} / \mathrm{g}_{(\mathrm{Pb}+\mathrm{C})}$. The early moments of the subsequent charge show a similar sloped tail, before reaching two successive very stable voltage plateaus

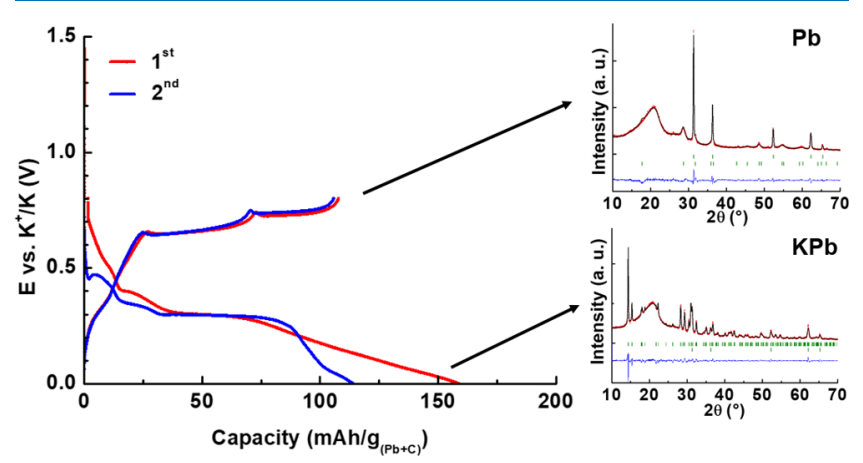

Figure 2. Voltage profile of the $\mathrm{Pb}$ electrode cycled between 0.0 and $0.8 \mathrm{~V}$ at $\mathrm{C} / 5$. Insets show the ex situ XRD patterns collected at the end of the first discharge (bottom, with residue of remaining $\mathrm{Pb}$ ) and at the end of the first charge (top, with $\mathrm{PbO}$ as minor impurity). 
at 0.65 and $0.72 \mathrm{~V}$. This sequence of processes is maintained during few cycles in discharge as well as in charge, producing a reversible capacity of $105 \mathrm{~mA} \mathrm{~h} / \mathrm{g}_{(\mathrm{Pb}+\mathrm{C})}$. Increasing the potential cut-off value above $0.8 \mathrm{~V}$ triggers again the parasitic reaction and strongly alters the reversible capacity (Figure S2).

In order to clarify the overall electrochemical mechanism, $\mathrm{XRD}$ patterns were collected ex situ at different stages. At the end of the discharge, crystalline $\mathrm{KPb}$ is evidenced with residual unreacted $\mathrm{Pb}$ (inset of Figure 2). Indeed, the XRD pattern can be indexed using the tetragonal space group $I 4_{1} /$ acd with refined cell parameters $(a=11.531(1) \AA$ and $c=18.855(1) \AA)$ in good agreement with the literature. ${ }^{40}$ The final formation of $\mathrm{KPb}$ also agrees with the $\mathrm{K}-\mathrm{Pb}$ thermodynamic phase diagram where $\mathrm{KPb}$ appears as the K-richest alloy. During the first discharge, the potassiation of the lead-based electrode is accompanied by (i) a significant electrochemical activity of the carbon additives toward potassium ions (Figure S3) and (ii) the likely formation of a solid electrolyte interphase (SEI) coming from electrolyte decomposition. Further investigations are ongoing in order to better understand the structure and the composition of the electrode/electrolyte interphase for both $\mathrm{Pb}$ and carbon additives, as well as its impact on capacity and capacity retention. At the end of charge, crystalline $\mathrm{Pb}$ is recovered (inset of Figure 2) with cell parameters similar to pristine $\mathrm{Pb}$. A small amount of $\mathrm{PbO}$ is also detected, most probably formed during electrode washing prior to the XRD measurement.

In order to better understand the complex electrochemical signature of $\mathrm{Pb}$ versus $\mathrm{K}$ and identify the phases formed during the reaction, operando XRD was carried out after a first activation cycle (Figure 3).

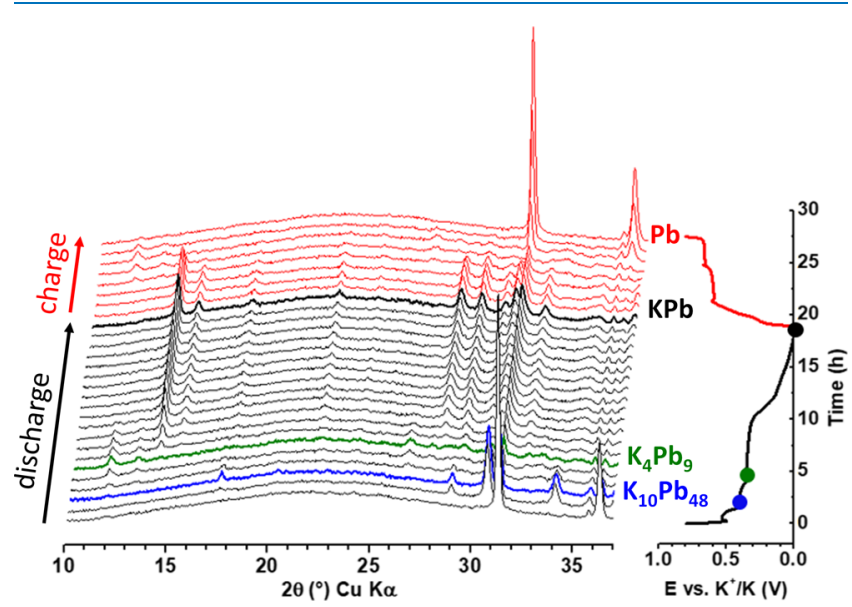

Figure 3. Operando XRD measurement of the $\mathrm{Pb}$ electrode during potassiation/depotassiation (left) with the corresponding voltage profile plotted as a function of time (right). Black and red patterns link to the discharge and the charge, respectively. Specific patterns in thicker lines are isolated in Figure 4 for better characterization.

As soon as the discharge progresses, diffraction peaks (111) and (200) of initial $\mathrm{Pb}$ (see Figure S4) decrease quickly, whereas new peaks appear at $17.5^{\circ}, 28.9^{\circ}, 30.7^{\circ}$, and $34^{\circ}$. The $\mathrm{XRD}$ pattern recorded at the end of the first potential plateau can be attributed to $\mathrm{K}_{10} \mathrm{~Pb}_{48}$, which crystallizes in the cubic space group $\bar{I} \overline{4} 3 m$ [inorganic crystal structure database (ICSD) no. 410090] (Figure 4a). ${ }^{41}$ On continuing the discharge process, the intensity of the peaks from $\mathrm{K}_{10} \mathrm{~Pb}_{48}$ decreases rapidly and the following patterns recorded during the second
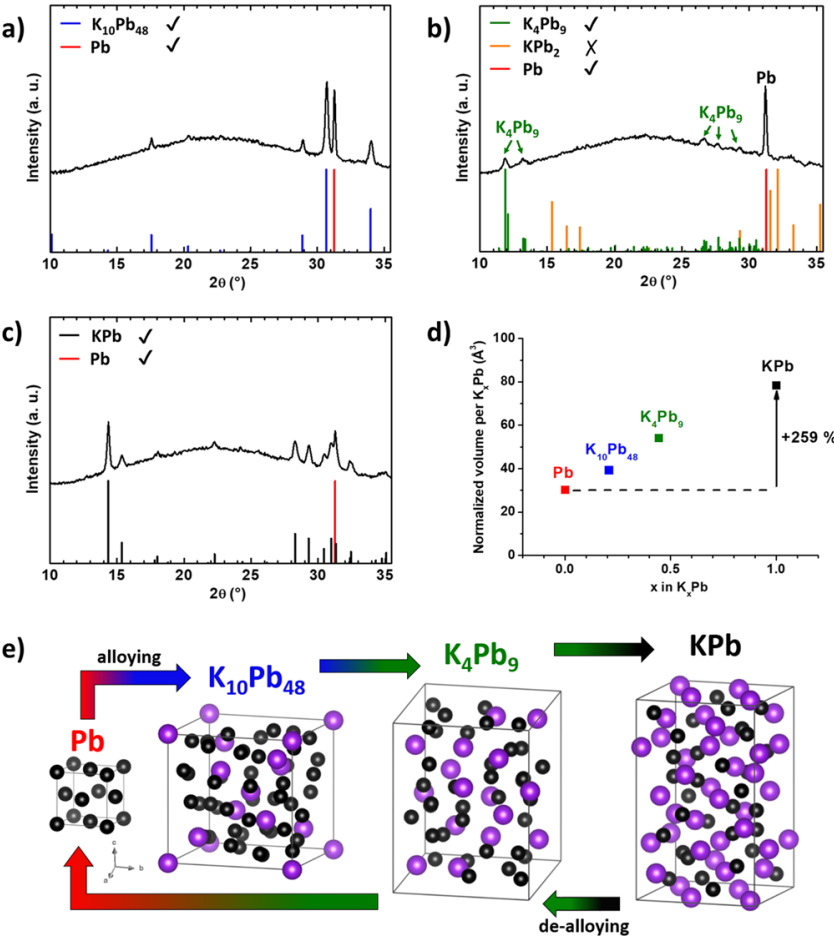

Figure 4. Specific XRD patterns recorded during the operando measurement (a) at the end of the first plateau (blue circle in Figure 3 ), (b) at the end of the second plateau (green circle in Figure 3), and (c) at the end of the overall discharge (black circle in Figure 3). The normalized volume evolution (d) illustrates the important alloying expansion. (e) Scheme of the potassiation/depotassiation of the lead electrode.

plateau show ill-defined diffraction peaks at $11.9^{\circ}, 13.2^{\circ}$, and $26.7^{\circ}$. At this moment, based on the stoichiometry of the reacted potassium, two different phases are possible: $\mathrm{KPb}_{2}$ (space group $\mathrm{Pb}_{3} / m m c$, ICSD no. 104613) or $\mathrm{K}_{4} \mathrm{~Pb}_{9}$ (space group $P 12_{1} / m 1$, ICSD no. 240029$){ }^{42,43}$ The pattern recorded at the end of the second plateau was thus isolated for deeper characterization: the set of new peaks matches well with $\mathrm{K}_{4} \mathrm{~Pb}_{9}$, whereas the most intense peaks of $\mathrm{KPb}_{2}$ are absent (Figure $4 \mathrm{~b}$ ). The final step of the discharge leads to the formation of crystalline $\mathrm{KPb}$ (Figure $4 \mathrm{c}$ ). The (111) reflection of $\mathrm{Pb}$ is still visible during the whole discharge, in agreement with the ex situ XRD (inset of Figure 2), which attests the only partial reaction of pristine $\mathrm{Pb}$ particles.

The following charge presents two voltage plateaus, which correspond to the transitions of $\mathrm{KPb}$ to $\mathrm{K}_{4} \mathrm{~Pb}_{9}$ and from $\mathrm{K}_{4} \mathrm{~Pb}_{9}$ directly to $\mathrm{Pb}$. The overall potassiation from $\mathrm{Pb}$ to $\mathrm{KPb}$ involves an important volumetric expansion $(+259 \%)$, which is logically larger than during the electrochemical formation of $\mathrm{LiPb}(+146 \%)$ and $\mathrm{NaPb}(+205 \%)$ (Figure $4 \mathrm{~d})$.

The alloying and de-alloying process of lead electrodes with potassium is schematically resumed in Figure 4e. To summarize, during the discharge (alloying) the potassiation of lead goes through two intermediate phases $\mathrm{K}_{10} \mathrm{~Pb}_{48}$ and $\mathrm{K}_{4} \mathrm{~Pb}_{9}$ before the formation of $\mathrm{KPb}$ at the end of the discharge. Upon charge, only one intermediate is observed, $\mathrm{K}_{4} \mathrm{~Pb}_{9}$, whereas no trace of $\mathrm{K}_{10} \mathrm{~Pb}_{48}$ is visible before the recovering of $\mathrm{Pb}$ metal. Interestingly, this mechanism differs from that calculated by the group of Ceder who mentioned a three-step process with $\mathrm{KPb}_{2}$ as one of the intermediates. ${ }^{4}$ The phases mentioned in the phase diagram do not seem to form, whereas 
the two intermediates identified by operando XRD are supposed to form only at high temperatures. This is not surprising, as the thermodynamic phase diagram is not always respected during electrochemical alloying (as previously observed in the case of $\mathrm{Sb}$ with sodium ${ }^{44,45}$ ), and in some cases, electrochemical reactions can lead to the formation of phases that are expected to form at high pressure and/or high temperature (as for $\mathrm{NiSb}_{2}$ with $\mathrm{Li}^{46}$ ).

The cycling performance of the $\mathrm{Pb} / \mathrm{K}$ cell at a $\mathrm{C} / 5$ rate is presented in Figure 5a. The first cycle presents a low
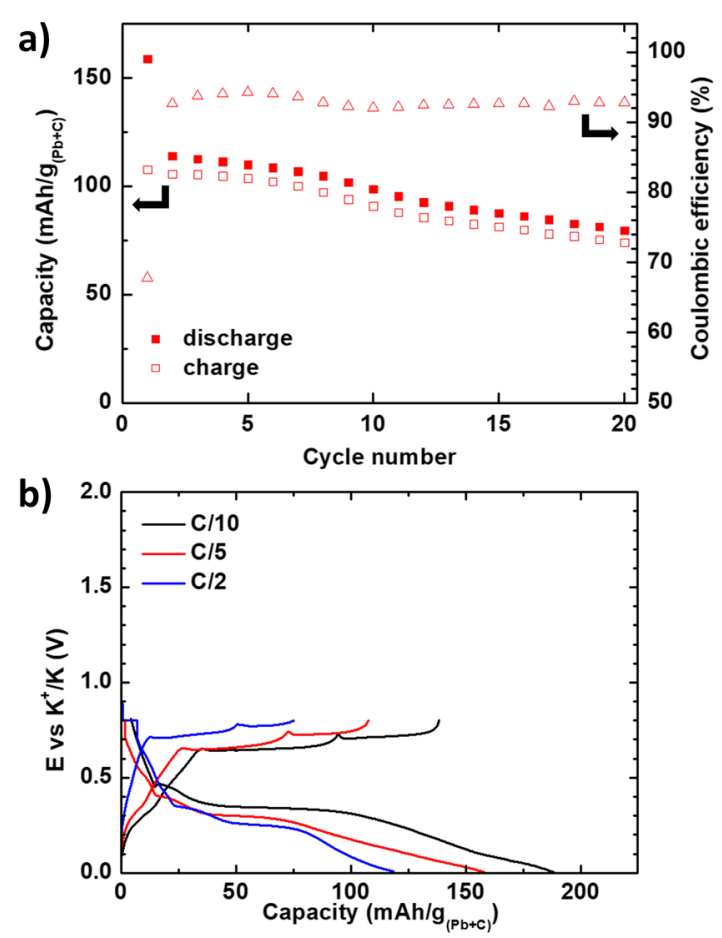

Figure 5. Electrochemical performance of $\mathrm{Pb}$ electrodes. (a) Charge/ discharge capacity (squares) and coulombic efficiency (triangle) at the $\mathrm{C} / 5$ rate and (b) first cycle at different current rates from $\mathrm{C} / 10$ to $\mathrm{C} /$ 2.

coulombic efficiency of $68 \%$, likely because of the formation of an SEI and the electrochemical activity of carbon included in the electrode formulation (Figure S3). The reversible charge capacity progressively decreases from $108 \mathrm{~mA} \mathrm{~h} / \mathrm{g}(485 \mathrm{~mA} \mathrm{~h} /$ $\left.\mathrm{cm}^{3}\right)$ to $75 \mathrm{~mA} \mathrm{~h} / \mathrm{g}\left(335 \mathrm{~mA} \mathrm{~h} / \mathrm{cm}^{3}\right)$ after 20 cycles. The capacity significantly decreases when the current rate is increased from $\mathrm{C} / 10$ to $\mathrm{C} / 2$ (Figure $5 \mathrm{~b}$ ).

\section{CONCLUSIONS}

The electrochemical potassiation of lead was investigated for the first time using specific cycling conditions in terms of current and potential window to prevent the passivation of the lead electrode at high potential. The galvanostatic profile showed three distinct steps during the discharge and only two during charge. The reaction mechanism revealed by operando $\mathrm{XRD}$ involves the formation of $\mathrm{K}_{10} \mathrm{~Pb}_{48}, \mathrm{~K}_{4} \mathrm{~Pb}_{9}$, and $\mathrm{KPb}$ during the discharge, whereas only $\mathrm{K}_{4} \mathrm{~Pb}_{9}$ is formed on going from $\mathrm{KPb}$ to $\mathrm{Pb}$. The reversible potassiation of lead is obtained for several cycles at the $\mathrm{C} / 5$ rate. This investigation confirms the interest in alloying-type materials for the development of rechargeable KIBs.

\section{EXPERIMENTAL SECTION}

Micrometric lead powder from Sigma-Aldrich (99.95\%, 325 mesh) was used as the active material. Electrode formulation was carried out under argon atmosphere by mixing the metallic powder $(70 \mathrm{wt} \%$ ) with carbon additives ( $9 \mathrm{wt} \%$ of Timcal CNergy Super C65, 9 wt \% of vapor-grown carbon fibers) and a polymeric binder (12 wt \% of polyvinylidene difluoride, Solef 5130 from Solvay). A slurry with anhydrous $\mathrm{N}$-methyl-2pyrrolidinone (99.5\% from Sigma-Aldrich) as solvent was homogeneously mixed by a planetary ball-milling $(1 \mathrm{~h})$, then tape-casted at $150 \mu \mathrm{m}$ on a thick copper foil, and finally dried for a few days at room temperature. The resulting film was finally dried overnight at $80{ }^{\circ} \mathrm{C}$ under dynamic vacuum. The final mass loading of the electrodes varied from 2.0 to $2.5 \mathrm{mg} /$ $\mathrm{cm}^{2}$.

Standard coin cells were assembled in an argon-filled glovebox with a counter electrode of potassium metal (Sigma-Aldrich) and a glass fiber separator (Whatman, GF/ D) soaked with an electrolyte made of KFSI salt (from Solvionic) dissolved in a 1:1 volumetric mixture of EC/DEC $(0.8 \mathrm{~mol} / \mathrm{L}$ of salt concentration $)$.

The electrochemical tests were performed in galvanostatic mode at room temperature using a research-grade potentiostat (MPG-2, BioLogic). Current rates ranged from $\mathrm{C} / 10$ to $\mathrm{C} / 2$ $(\mathrm{C} / n$ meaning $1 \mathrm{~mol}$ of $\mathrm{K}$ per mol of $\mathrm{Pb}$ in $n$ hours). The capacities are presented in $\mathrm{mA} \mathrm{h} / \mathrm{g}$ of composite $(\mathrm{Pb}+\mathrm{C})$ in order to take into account the activity of carbon from the formulation. For the ex situ XRD measurements after cycling, coin cells were disassembled under argon atmosphere in a glovebox, and the electrodes were washed twice with $1 \mathrm{~mL}$ of DEC and then detached from the current collectors.

In order to reveal the electrochemical mechanism, an operando XRD analysis was carried out using a dedicated electrochemical cell equipped with a beryllium window. Here, the above described electrode slurry was tape-casted onto a very thin aluminum foil (thickness $2 \mu \mathrm{m}$ ). XRD patterns were continuously collected on an Empyrean 2 theta/omega diffractometer (PANalytical) equipped with $\mathrm{Cu} \mathrm{K} \alpha$ radiation $\left(10^{\circ}-37^{\circ} 2 \theta\right.$ range for an acquisition time of $\left.1 \mathrm{~h}\right)$.

\section{ASSOCIATED CONTENT}

\section{S Supporting Information}

The Supporting Information is available free of charge on the ACS Publications website at DOI: 10.1021/acsomega.8b01369.

Galvanostatic profile of $\mathrm{K} / \mathrm{Pb}$ half cells with different potential windows and with the appliance of current pulse, contribution of carbon additives to the capacity, $\mathrm{XRD}$ pattern of $\mathrm{Pb}$ electrodes at the beginning of the operando XRD analysis, and summary of gravimetric and volumetric capacities of p-block elements and graphite (PDF)

\section{AUTHOR INFORMATION}

\section{Corresponding Author}

*E-mail: romain.berthelot@umontpellier.fr (R.B.).

ORCID $\odot$

Lorenzo Stievano: 0000-0001-8548-0231

Laure Monconduit: 0000-0003-3698-856X

\section{Notes}

The authors declare no competing financial interest. 


\section{ACKNOWLEDGMENTS}

The authors thank the French National Research Agency (STORE-EX Labex Project ANR-10-LABX-76-01).

\section{REFERENCES}

(1) Tarascon, J.-M.; Armand, M. Issues and Challenges Facing Rechargeable Lithium Batteries. Nature 2001, 414, 359-367.

(2) Tarascon, J.-M. Is Lithium the New Gold? Nat. Chem. 2010, 2, 510.

(3) Kubota, K.; Dahbi, M.; Hosaka, T.; Kumakura, S.; Komaba, S. Towards K-Ion and Na-Ion Batteries as "Beyond Li-Ion". Chem. Rec. 2018, 18, 459-479.

(4) Kim, H.; Kim, J. C.; Bianchini, M.; Seo, D.-H.; Rodriguez-Garcia, J.; Ceder, G. Recent Progress and Perspective in Electrode Materials for K-Ion Batteries. Adv. Energy Mater. 2018, 8, 1702384.

(5) Okoshi, M.; Yamada, Y.; Komaba, S.; Yamada, A.; Nakai, H. Theoretical Analysis of Interactions between Potassium Ions and Organic Electrolyte Solvents: A Comparison with Lithium, Sodium, and Magnesium Ions. J. Electrochem. Soc. 2017, 164, A54-A60.

(6) Recham, N.; Rousse, G.; Sougrati, M. T.; Chotard, J.-N.; Frayret, C.; Mariyappan, S.; Melot, B. C.; Jumas, J.-C.; Tarascon, J.-M. Preparation and Characterization of a Stable $\mathrm{FeSO}_{4} \mathrm{~F}$-Based Framework for Alkali Ion Insertion Electrodes. Chem. Mater. 2012, 24, 4363-4370.

(7) Chihara, K.; Katogi, A.; Kubota, K.; Komaba, S. KVPO ${ }_{4} \mathrm{~F}$ and $\mathrm{KVOPO}_{4}$ toward 4 volt-class potassium-ion batteries. Chem. Commun. 2017, 53, 5208-5211.

(8) Vaalma, C.; Giffin, G. A.; Buchholz, D.; Passerini, S. NonAqueous K-Ion Battery Based on Layered $\mathrm{K}_{0.3} \mathrm{MnO}_{2}$ and Hard Carbon/Carbon Black. J. Electrochem. Soc. 2016, 163, A1295-A1299.

(9) Hironaka, Y.; Kubota, K.; Komaba, S. P2- and P3- $\mathrm{K}_{\mathrm{x}} \mathrm{CoO}_{2}$ as an Electrochemical Potassium Intercalation Host. Chem. Commun. 2017, 53, 3693-3696.

(10) Chen, Y.; Luo, W.; Carter, M.; Zhou, L.; Dai, J.; Fu, K.; Lacey, S.; Li, T.; Wan, J.; Han, X.; et al. Organic Electrode for Non-Aqueous Potassium-Ion Batteries. Nano Energy 2015, 18, 205-211.

(11) Padigi, P.; Thiebes, J.; Swan, M.; Goncher, G.; Evans, D.; Solanki, R. Prussian Green: A High Rate Capacity Cathode for Potassium Ion Batteries. Electrochim. Acta 2015, 166, 32-39.

(12) Wu, X.; Jian, Z.; Li, Z.; Ji, X. Prussian White Analogues as Promising Cathode for Non-Aqueous Potassium-Ion Batteries. Electrochem. Commun. 2017, 77, 54-57.

(13) Chong, S.; Chen, Y.; Zheng, Y.; Tan, Q.; Shu, C.; Liu, Y.; Guo, Z. Potassium Ferrous Ferricyanide Nanoparticles as a High Capacity and Ultralong Life Cathode Material for Nonaqueous Potassium-Ion Batteries. J. Mater. Chem. A 2017, 5, 22465-22471.

(14) Bie, X.; Kubota, K.; Hosaka, T.; Chihara, K.; Komaba, S. A Novel K-Ion Battery: Hexacyanoferrate(II)/Graphite Cell. J. Mater. Chem. A 2017, 5, 4325-4330.

(15) Liu, L.; Chen, Y.; Xie, Y.; Tao, P.; Li, Q.; Yan, C. Understanding of the Ultrastable K-Ion Storage of Carbonaceous Anode. Adv. Funct. Mater. 2018, 28, 1801989.

(16) Luo, W.; Wan, J.; Ozdemir, B.; Bao, W.; Chen, Y.; Dai, J.; Lin, H.; Xu, Y.; Gu, F.; Barone, V.; et al. Potassium Ion Batteries with Graphitic Materials. Nano Lett. 2015, 15, 7671-7677.

(17) Share, K.; Cohn, A. P.; Carter, R. E.; Pint, C. L. Mechanism of Potassium Ion Intercalation Staging in Few Layered Graphene from in Situ Raman Spectroscopy. Nanoscale 2016, 8, 16435-16439.

(18) Jian, Z.; Luo, W.; Ji, X. Carbon Electrodes for K-Ion Batteries. J. Am. Chem. Soc. 2015, 137, 11566-11569.

(19) Sultana, I.; Rahman, M. M.; Chen, Y.; Glushenkov, A. M. Potassium-Ion Battery Anode Materials Operating through the Alloying-Dealloying Reaction Mechanism. Adv. Funct. Mater. 2018, 28, 1703857.

(20) Zhang, W.; Pang, W. K.; Sencadas, V.; Guo, Z. Understanding High-Energy-Density $\mathrm{Sn}_{4} \mathrm{P}_{3}$ Anodes for Potassium-Ion Batteries. Joule 2018, 2, 1534.
(21) Zhang, W.; Mao, J.; Li, S.; Chen, Z.; Guo, Z. Phosphorus-Based Alloy Materials for Advanced Potassium-Ion Battery Anode. J. Am. Chem. Soc. 2017, 139, 3316-3319.

(22) Sultana, I.; Rahman, M. M.; Ramireddy, T.; Chen, Y.; Glushenkov, A. M. High Capacity Potassium-Ion Battery Anodes Based on Black Phosphorus. J. Mater. Chem. A 2017, 5, 2350623512.

(23) Xiong, P.; Bai, P.; Tu, S.; Cheng, M.; Zhang, J.; Sun, J.; Xu, Y. Red Phosphorus Nanoparticle@3D Interconnected Carbon Nanosheet Framework Composite for Potassium-Ion Battery Anodes. Small 2018, 14, 1802140

(24) McCulloch, W. D.; Ren, X.; Yu, M.; Huang, Z.; Wu, Y. Potassium-Ion Oxygen Battery Based on a High Capacity Antimony Anode. ACS Appl. Mater. Interfaces 2015, 7, 26158-26166.

(25) Han, C.; Han, K.; Wang, X.; Wang, C.; Li, Q.; Meng, J.; Xu, X.; He, Q.; Luo, W.; Wu, L.; et al. Three-Dimensional Carbon Network Confined Antimony Nanoparticles Anode for High-Capacity K-Ion Batteries. Nanoscale 2018, 10, 6820.

(26) Huang, J.; Lin, X.; Tan, H.; Zhang, B. Bismuth Microparticles as Advanced Anodes for Potassium-Ion Battery. Adv. Energy Mater. 2018, 8, 1703496.

(27) Zhang, Q.; Mao, J.; Pang, W. K.; Zheng, T.; Sencadas, V.; Chen, Y.; Liu, Y.; Guo, Z. Boosting the Potassium Storage Performance of Alloy-Based Anode Materials via Electrolyte Salt Chemistry. Adv. Energy Mater. 2018, 8, 1703288.

(28) Lei, K.; Wang, C.; Liu, L.; Luo, Y.; Mu, C.; Li, F.; Chen, J. A Porous Network of Bismuth Used as the Anode Material for HighEnergy-Density Potassium-Ion Batteries. Angew. Chem., Int. Ed. 2018, 57, 4687-4691.

(29) Sultana, I.; Ramireddy, T.; Rahman, M. M.; Chen, Y.; Glushenkov, A. M. Tin-Based Composite Anodes for Potassium-Ion Batteries. Chem. Commun. 2016, 52, 9279-9282.

(30) Ramireddy, T.; Kali, R.; Jangid, M. K.; Srihari, V.; Poswal, H. K.; Mukhopadhyay, A. Insights into Electrochemical Behavior, Phase Evolution and Stability of Sn upon K-Alloying/de-Alloying via In Situ Studies. J. Electrochem. Soc. 2017, 164, A2360-A2367.

(31) Wang, Q.; Zhao, X.; Ni, C.; Tian, H.; Li, J.; Zhang, Z.; Mao, S. X.; Wang, J.; Xu, Y. Reaction and Capacity-Fading Mechanisms of Tin Nanoparticles in Potassium-Ion Batteries. J. Phys. Chem. C 2017, 121, 12652.

(32) Zhang, W.; Yang, J.; Wu, X.; Hu, Y.; Yu, W.; Wang, J.; Dong, J.; Li, M.; Liang, S.; Hu, J.; et al. A Critical Review on Secondary Lead Recycling Technology and Its Prospect. Renewable Sustainable Energy Rev. 2016, 61, 108-122.

(33) Ellis, L. D.; Wilkes, B. N.; Hatchard, T. D.; Obrovac, M. N. In Situ XRD Study of Silicon, Lead and Bismuth Negative Electrodes in Nonaqueous Sodium Cells. J. Electrochem. Soc. 2014, 161, A416A421.

(34) Darwiche, A.; Dugas, R.; Fraisse, B.; Monconduit, L. Reinstating Lead for High-Loaded Efficient Negative Electrode for Rechargeable Sodium-Ion Battery. J. Power Sources 2016, 304, 1-8.

(35) Periyapperuma, K.; Tran, T. T.; Purcell, M. I.; Obrovac, M. N. The Reversible Magnesiation of Pb. Electrochim. Acta 2015, 165, $162-165$.

(36) Ji, B.; Zhang, F.; Song, X.; Tang, Y. A Novel Potassium-IonBased Dual-Ion Battery. Adv. Mater. 2017, 29, 1700519.

(37) Courtney, I. A.; Dahn, J. R. Electrochemical and In Situ X-Ray Diffraction Studies of the Reaction of Lithium with Tin Oxide Composites. J. Electrochem. Soc. 1997, 144, 2045.

(38) Tamura, N.; Ohshita, R.; Fujimoto, M.; Fujitani, S.; Kamino, M.; Yonezu, I. Study on the Anode Behavior of Sn and $\mathrm{Sn}-\mathrm{Cu}$ Alloy Thin-Film Electrodes. J. Power Sources 2002, 107, 48-55.

(39) Beattie, S. D.; Dahn, J. R. Single Bath, Pulsed Electrodeposition of Copper-Tin Alloy Negative Electrodes for Lithium-ion Batteries. J. Electrochem. Soc. 2003, 150, A894.

(40) Hewaidy, I. F.; Busmann, E.; Klemm, W. Die Struktur Der ABVerbindungen Der Schweren Alkalimetalle Mit Zinn Und Blei. Z. Anorg. Allg. Chem. 1964, 328, 283-293. 
(41) Fässler, T. F.; Kronseder, C.; Wörle, M. Eine Neue Kolorierungsvariante Des A-Mn-Strukturtyps Mit Hauptgruppenelementen in $\mathrm{K}_{5} \mathrm{~Pb}_{24}$ - Kristallstruktur, Supraleitung Und StrukturEigenschafts-Beziehung. Z. Anorg. Allg. Chem. 1999, 625, 15-23.

(42) Gilde, D. Die Kristallstruktur Des $\mathrm{KPb}_{2}$. Z. Anorg. Allg. Chem. 1956, 284, 142-143.

(43) Queneau, V.; Sevov, S. C. Synthesis and Structure of the ZintlPhase $\mathrm{K}_{4} \mathrm{~Pb}_{9}$ Containing Isolated $\mathrm{Pb}_{9}{ }^{4-}$ Clusters of Two Different Geometries. Inorg. Chem. 1998, 37, 1358-1360.

(44) Darwiche, A.; Marino, C.; Sougrati, M. T.; Fraisse, B.; Stievano, L.; Monconduit, L. Better Cycling Performances of Bulk Sb in Na-Ion Batteries Compared to Li-Ion Systems: An Unexpected Electrochemical Mechanism. J. Am. Chem. Soc. 2012, 134, 20805-20811.

(45) Allan, P. K.; Griffin, J. M.; Darwiche, A.; Borkiewicz, O. J.; Wiaderek, K. M.; Chapman, K. W.; Morris, A. J.; Chupas, P. J.; Monconduit, L.; Grey, C. P. Tracking Sodium-Antimonide Phase Transformations in Sodium-Ion Anodes: Insights from Operando Pair Distribution Function Analysis and Solid-State NMR Spectroscopy. J. Am. Chem. Soc. 2016, 138, 2352-2365.

(46) Villevieille, C.; Ionica-Bousquet, C.-M.; Ducourant, B.; Jumas, J.-C.; Monconduit, L. $\mathrm{NiSb}_{2}$ as Negative Electrode for Li-Ion Batteries: An Original Conversion Reaction. J. Power Sources 2007, 172, 388-394. 